\title{
Geochemistry of calcite-precipitating waters of the European Northeast
}

\author{
Tatiana P. Mityusheva ${ }^{1, *}$ \\ ${ }^{1}$ IG of the Komi Science Centre of the RAS, 167100 Syktyvkar, Russia
}

\begin{abstract}
The geochemistry of natural calcite-precipitating waters of the European northeast was presented in this paper. The chemical composition and main hydro-chemical type of these surface and underground waters are various, TDS from 239 to $2090 \mathrm{mg} / \mathrm{L}$. The waters are supersaturated with respect to calcite, there are favorable hydrochemical conditions for formation recent continental carbonates (calcareous tufa, charophyta, calcareous crusts on macrophytes) in the conditions of moderate continental climate.
\end{abstract}

\section{Introduction}

The study of interactions in the water-carbonates system is relevant because of a wide distribution, diversity and complexity of calcite-precipitating biogeosystems formed in continental conditions.

Data about the chemical composition of the waters are presented in the numerous works characterizing paleo- and recent carbonates from various regions of the world. Travertine precipitates form springs of underground waters is widely known (Pedley, 1990; Ford and Pedley, 1996; Pentecost, 1990, 1995, 2005; Lavrushin, etc., 2006, et al.). Many works were devoted to the characteristic of chara incrustations and carbonate deposits of lakes (Hutchinson, 1975; Murphy et al. 1983; Krause, 1981, 1997 et al.).

The main purpose of this paper is to characterize the chemical features of calciteprecipitating surface and underground waters of the European northeast.

The area of study is in high widths within $60^{\circ} 30^{\prime}-67^{\circ} 20^{\prime} \mathrm{N}$ and $45^{\circ} 00^{\prime}-61^{\circ} 00^{\prime} \mathrm{E}$ in the northeast of the East European platform, far from warm Atlantic and close to Arctic ocean, which result in moderate continental climate with low temperature (mid-annual temperature $\left.-1 \ldots-5^{\circ} \mathrm{C}\right)$ and a significant amount of atmospheric precipitations $(600-800 \mathrm{~mm}$ per year), exceeding evaporation.

The territories, where areas with recent carbonate sedimentation were investigated, were composed of carbonaceous Upper Devonian, sulphate-carbonate-terrigenous and carbonateterrigenous Permian and terrigenous Middle to Upper Jurassic deposits.

\footnotetext{
*Corresponding author: mityusheva@geo.komisc.ru
} 


\section{Sampling and analysis}

The studies were conducted with water objects during summer low-flow period 2006-2017. We observed limestone tuffs (travertines) on three areas (Fig. 1) in springs and stream: area 1 - Pymvashor (samples 1a/06, 1b/06), area 5 - Ib (samples I3/09, I21/09, I22-2/09) and area 6 - Vaskin Klyuch (samples 40-2/09, 42/09). In shallow parts of lakes Chermanty (area 3, sample AA11/14) and in the group of "Paraskin Lakes" (area 2, samples 1/07, 1a/07) Chara algae inhabited and limnocalcites formed. In the waters of the Vym River (area 4, sample T9/17), we studied biomineral crusts on macrophytes of the Potamogetonáceae family.

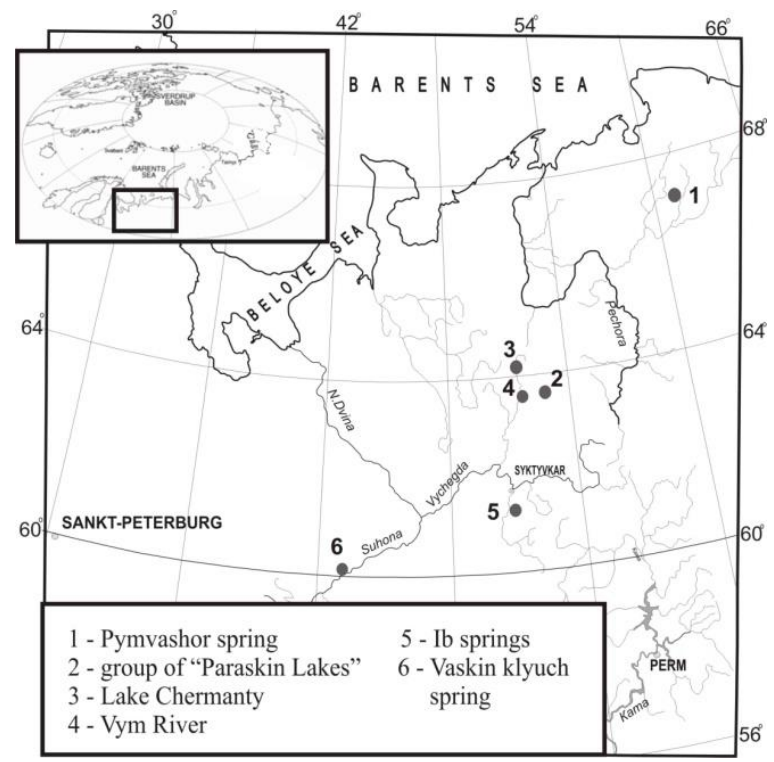

Fig. 1. Location of the study area and sampling sites in the European Northeast.

The temperatures (T), electrical conductivity (EC), total dissolved solids (TDS) and $\mathrm{pH}$ of waters were measured using a portable Hanna meter in situ. Analyses were carried out in the laboratories of Institute of Biology Komi Science Centre RAS (Syktyvkar) using standard techniques.

The chemical analysis of the waters of the studied sites showed varying composition and degree of mineralization, TDS varied from 239 to saline $2090 \mathrm{mg} / \mathrm{L}$ (Table 1). The $\mathrm{pH}$ value of water is neutral-alkaline (6.8-7.9). The temperature of water is characterized by a wide range of values from 4.3 to $36.1{ }^{\circ} \mathrm{C}$. The main hydro-chemical type of the waters is different.. In the composition of the waters, each of three main anions may prevail; $\mathrm{HCO}_{3}$ is present in the amount of 54-437 mg/L and $\mathrm{SO}_{4}-20-960 \mathrm{mg} / \mathrm{L}$, which is 7-94 and 5-94\% of total anions respectively. Ca $(78-420 \mathrm{mg} / \mathrm{L})$ prevails in the cationic composition of water (18-90 \% of total cations), with the exception of the salt waters from the Pymvashor springs, where $\mathrm{Na}$ is dominating $(550-570 \mathrm{mg} / \mathrm{L}$ and $72 \%)$. The content of $\mathrm{SO}_{4}$ is in inverse proportion to $\mathrm{Ca}$ and the coefficient reflecting the water transformation $m^{*} \mathrm{Mg} / \mathrm{mCa}$. For the carbonate-depositing waters the condition are fulfilled [1] $2 m_{\mathrm{Ca}^{2+}}>m_{\mathrm{HCO}_{3}^{-}}+2 m_{\mathrm{CO}_{3}^{2-}}$ and $m_{\mathrm{Ca}^{2+}}>m_{\mathrm{SO}_{4}^{2-}}$.

\footnotetext{
${ }^{*} m$ - concentration ion, $\mathrm{mol} / \mathrm{L}$
} 
SOLMINEQ calculation indicates that the water samples of the Vym River (T9/16), lakes (AA11/14, 1/07, 1a/07, 1a-15/07), Pymvashor springs (1a/06, 16/06), spring Vaskin Klyuch (40-2/09) are supersaturated with respect to calcite (Table 1) and are not saturated with respect to gypsum.

Concerning the associated carbonate deposits, the researches [2-5] showed that all were composed of bio-chemogenic calcite $\left(\mathrm{CaCO}_{3}\right)$, while amorphous silica was also always present due to the great diversity of diatoms. The amount of $\mathrm{CaO}$ in the carbonates is more than 30 wt. \%, which indicates a high content of calcite, reaching $99 \mathrm{~mol}$ \% in terms of standard minerals in the soluble part of the samples. Also the composition of deposits in all the analyzed samples contains sulfur $\left(\mathrm{as}_{3}\right)$, which reflects the presence of sulfate-ion in the waters (Table 1).

The formation of $\mathrm{CaCO}_{3}$ on the artesian springs is usually observed at some distance from the waters outcrop at the down-stream. On the Pymvashor springs, recent sedimentation of calcareous tuffs (travertines) occurs at a distance of more than $100 \mathrm{~m}$, in the Ib spring - more than $60 \mathrm{~m}$, on Vaskin klyuch - $20 \mathrm{~m}$. It is interesting that the process of biomineralization is observed both during cooling of warm waters (east of Pymvashor) [2], and with increasing temperature of the water. For example, at the Ib spring at outflow (on map No. 5), waters have a temperature of $6.8^{\circ} \mathrm{C}$ (I21/09), and only when it rises to 8.2 ${ }^{\circ} \mathrm{C}$ (I22-2/09) $\mathrm{CaCO}_{3}$ precipitates along the water flow (in area $\sim 20 \mathrm{~m}$ ). The following changes in physical and chemical properties of water are observed: increasing $\mathrm{pH}$, decreasing content of water-soluble $\mathrm{CO}_{2}, \mathrm{Ca}$ and $\mathrm{HCO}_{3}$. A similar picture is observed in the Vaskin klyuch spring $(42 / 09 \rightarrow 40-2 / 09)$ : when falling from a height (travertine terrace) with increasing temperature $\left(\right.$ at $0.7^{\circ} \mathrm{C}$ ) and alkalinity of water, there is a sharp decrease in the amount of carbon dioxide, TDS, components $\mathrm{CaCO}_{3}$. The excess of the molar $\mathrm{Ca}$ content over the anions $\left(\mathrm{HCO}_{3}+\mathrm{CO}_{3}\right)$ in the waters of the studied artesian springs reaches 1-15 times, and therefore, there are conditions for the deposition of chemogenic $\mathrm{CaCO}_{3}$. For waters, depositing calcareous tuffs, the hydrochemical coefficients $m M g / m C a$ are $0.2-0.72$, and $\mathrm{mCa}_{\mathrm{MSO}} \mathrm{MS}_{4} 2.1-10.3$.

The studied lakes Chermanty and the group "Paraskin Lakes" (on map No. 2, 3) in which charophytes are formed (and carbonate sediments) are located within the Timan Ridge. A distinctive feature of the tectonic-karst lake waters is their $\mathrm{HCO}_{3}-\mathrm{SO}_{4}\left(\mathrm{SO}_{4}\right.$ $\mathrm{HCO}_{3}$ ) or $\mathrm{SO}_{4}-\mathrm{Ca}$ hydro-chemical type (Table 1), which is conditioned by the mineral composition of Permian terrigenous-carbonate rocks of the watershed and a significant part of karst water [3, 4]. Charophytes were found in shallow parts in lakes with a high salinity and in freshwaters (in which mineralization increases with depth, sample 1a-15/07 characterizes water composition selected on depth $15 \mathrm{~m}$ ). TDS of lake waters ranges within $275-1625 \mathrm{mg} / \mathrm{L}$. In the waters of the Vym river, which flows through the territory of Timan with similar geological and geochemical conditions, 5 sites with recent biomineral crusts on macrophytes were studied (on map No. 4). Calcite crusts and charophytes were found in neutral-alkaline waters with respect to $\mathrm{pH}(7.3-8.8)$, with a content of dissolved $\mathrm{CO}_{2}$ of $0.3-12.5 \mathrm{mg} / \mathrm{L}$ and a low water temperature (in summer period not more than $18{ }^{\circ} \mathrm{C}$ ). The ratios of $\mathrm{mMg} / \mathrm{mCa}$ and $\mathrm{mCa}_{\mathrm{CSSO}}$ in surface calcite-precipitating waters are lower than in waters of the springs (0.06-0.21) and (1.1-3.1) respectively. For waters of lakes and Vym river, the concentration of $\mathrm{Ca}$ also exceeds carbonate alkalinity and there are favorable hydrochemical conditions for the formation of $\mathrm{CaCO}_{3}$.

\section{Conclusions}

Our studies of the chemical composition of surface and underground calcite-precipitating waters have shown the complexity and diversity of interactions in the open water-rock system. The given examples of changes in the geochemistry of aquatic systems of the 
European Northeast indicate the possibility of formation of recent continental carbonate sediments (calcite) of chemogenic nature with the undoubted important role of microorganisms at low temperatures in natural waters with a high content of $\mathrm{Ca}$ and $\mathrm{HCO}_{3}$ at obligatory presence of $\mathrm{SO}_{4}$.

\section{References}

1. S.R. Kraynov, B.N. Ryzenko, V.M. Shvets, Geochemistry of ground waters. Theoretical, applied and environmental aspects. Moscow (in Russian) 677 (2004)

2. V.I. Silaev, I.I. Chajkovski, T.P. Mityusheva, A.F. Khazov Recent carbonate mineralizations on evaporated and sediment-diagenezis izotop-geochemical barriers. Syktyvkar, 2 (64), 68 (2008) (in Russian)

3. T.P. Mityusheva, E.N. Patova, Estimation of the possibility of modern mineral formation based on geochemical modeling of interactions in the water - rock system using the example of Timan karst lakes, Problems and prospects of modern mineralogy (Yushkin memorial seminar 2014), Syktyvkar, 232-235 (2014) (in Russian)

4. T.P. Mityusheva, V.I. Katkova, The role of chara algae in the continental carbonate sedimentation of lake Chermanty (Timan), Bulletin of Moscow society of naturalists. Geol., 5, 41-51 (2015) (in Russian)

5. V.I. Katkova, T.P. Mityusheva, B.I. Teteryuk, Features of the mineralization of hydrobionts of the Potamogetonáceae from the Vym River (Komi Republic), Proceedings of Komi SC UB RAS (to be published). 
Table 1.Chemical composition of calcite-precipitating waters of European Northeast.

\begin{tabular}{|c|c|c|c|c|c|c|c|c|c|c|c|c|c|c|c|c|c|}
\hline \multirow{2}{*}{$\begin{array}{c}\text { Area on } \\
\text { map. } \\
\text { (Fig. 1) }\end{array}$} & \multirow[b]{2}{*}{$\begin{array}{c}\text { Sample } \\
\text { no. }\end{array}$} & \multirow[b]{2}{*}{$\begin{array}{c}\text { Ages of host } \\
\text { rocks }\end{array}$} & \multirow[b]{2}{*}{$\begin{array}{c}\mathrm{CaCO}_{3} \\
\text { biomineral }\end{array}$} & \multirow[b]{2}{*}{ pH } & $\mathbf{T}$ & TDS & $\mathrm{CO}_{2}$ & $\mathbf{N a}$ & $\mathbf{C a}$ & Mg & $\mathrm{Cl}$ & $\mathrm{SO}_{4}$ & $\mathrm{HCO}_{3}$ & \multirow[b]{2}{*}{$m M g / m C a$} & \multirow[b]{2}{*}{$\mathrm{mCa} / \mathrm{mSO}_{4}$} & \multirow[b]{2}{*}{$\begin{array}{c}\text { SI } \\
\text { for calcite }\end{array}$} & \multirow[b]{2}{*}{$\begin{array}{l}\text { Main hydro- } \\
\text { chemical type }\end{array}$} \\
\hline & & & & & ${ }^{\circ} \mathrm{C}$ & \multicolumn{8}{|c|}{$\mathrm{mg} / \mathrm{L}$} & & & & \\
\hline 1 & $1 \mathrm{a} / 06$ & $\mathrm{D}_{3}-\mathrm{C}_{1}$ & calcareous tufa & 7.93 & 26.1 & 2089.7 & 3.30 & 570 & 127.7 & 37.0 & 1050 & 145 & 150 & 0.48 & 2.1 & 0.69 & $\mathrm{Cl}-\mathrm{Na}$ \\
\hline 1 & $16 / 06$ & $\mathrm{D}_{3}-\mathrm{C}_{1}$ & calcareous tufa & 7.98 & 25.8 & 2065.6 & 3.58 & 550 & 121 & 36.0 & 1070 & 120 & 159 & 0.49 & 2.4 & 0.47 & $\mathrm{Cl}-\mathrm{Na}$ \\
\hline 2 & $1 / 07$ & $\mathrm{P}_{2}$ & charophyta & 8.78 & 12.2 & 353.2 & 0.25 & 5.5 & 107 & 13.2 & 0.2 & 82 & 124 & 0.20 & 3.1 & 1.25 & $\begin{array}{c}\mathrm{HCO}_{3}-\mathrm{SO}_{4} \\
-\mathrm{Ca}\end{array}$ \\
\hline 2 & $1 \mathrm{a} / 07$ & $\mathrm{P}_{2}$ & charophyta & 8.41 & 7.3 & 408.4 & 8.03 & 5.5 & 110 & 13.5 & 0.8 & 115 & 139 & 0.20 & 2.3 & 0.91 & $\begin{array}{c}\mathrm{SO}_{4}-\mathrm{HCO}_{3} \\
-\mathrm{Ca}\end{array}$ \\
\hline 2 & $1 \mathrm{a}-15 / 07$ & $\mathrm{P}_{2}$ & - & 7.68 & 6 & 723.4 & 5.52 & 6.9 & 298 & 22.7 & 1.4 & 197 & 159 & 0.13 & 3.6 & 0.57 & $\begin{array}{c}\mathrm{SO}_{4}-\mathrm{HCO}_{3} \\
-\mathrm{Ca}\end{array}$ \\
\hline 3 & AA11/14 & $\mathrm{P}_{1}$ & charophyta & 7.28 & 15.7 & 1625.4 & 12.56 & 27 & 420 & 14.6 & 42 & 960 & 160 & 0.06 & 1.1 & 0.31 & $\mathrm{SO}_{4}-\mathrm{Ca}$ \\
\hline 4 & T9/17 & $\mathrm{P}_{2}$ & $\begin{array}{c}\text { crust on } \\
\text { macrophytes }\end{array}$ & 7.89 & 14.0 & 573.7 & 3.81 & 5.9 & 125 & 15.9 & 2.1 & 260 & 164 & 0.21 & 1.2 & 0.77 & $\begin{array}{c}\mathrm{SO}_{4}-\mathrm{HCO}_{3} \\
-\mathrm{Ca} \\
\end{array}$ \\
\hline 5 & $\mathrm{I} 21 / 09$ & $\mathrm{~J}_{2}$ & - & 7.19 & 6.8 & 327.5 & 9.22 & 4.7 & 154 & 18.3 & 3.6 & 71 & 73.7 & 0.2 & 5.2 & -0.37 & $\begin{array}{c}\mathrm{SO}_{4}-\mathrm{HCO}_{3} \\
-\mathrm{Ca} \\
\end{array}$ \\
\hline 5 & I22-2/09 & $\mathrm{J}_{2}$ & calcareous tufa & 7.40 & 8.2 & 300.6 & 4.18 & 4.7 & 133 & 19.0 & 3.1 & 84 & 54.3 & 0.24 & 3.8 & -0.34 & $\begin{array}{c}\mathrm{SO}_{4}-\mathrm{HCO}_{3} \\
-\mathrm{Ca}\end{array}$ \\
\hline 5 & $\mathrm{I} 3 / 09$ & $\mathrm{~J}_{2}$ & calcareous tufa & 7.12 & 6.4 & 239.2 & 10.46 & 3.3 & 98 & 23.1 & 5.4 & 29 & 79.3 & 0.39 & 8.1 & -0.63 & $\begin{array}{c}\mathrm{HCO}_{3}-\mathrm{SO}_{4} \\
-\mathrm{Ca}-\mathrm{Mg}\end{array}$ \\
\hline 6 & $42 / 09$ & $\mathrm{P}_{3}$ & - & 7.30 & 4.3 & 589.0 & 15.60 & 5.4 & 89 & 34.0 & 0.6 & 21 & 437 & 0.63 & 10.3 & -0.20 & $\begin{array}{l}\mathrm{HCO}_{3-}- \\
\mathrm{Ca}-\mathrm{Mg} \\
\end{array}$ \\
\hline 6 & $40-2 / 09$ & $\mathrm{P}_{3}$ & calcareous tufa & 7.76 & 5 & 557.9 & 1.35 & 5.4 & 78 & 34.0 & 0.8 & 20 & 417 & 0.72 & 9.2 & 0.66 & $\begin{array}{l}\mathrm{HCO}_{3-} \\
\mathrm{Ca}-\mathrm{Mg}\end{array}$ \\
\hline
\end{tabular}

SI - logarithmic ratio of activity to solubility products for a mineral. 